\title{
Seksuell traumatisering av barn og selvmordsatferd
}

Ved Ingebjørg Hestetun

\section{"Er det noen andre muligheter?"..."Selvmord? Jeg har tenkt på det óg."}

Sitatet er hentet fra ungdomsromanen "Abby, min elskede". Ordene tilhører Abby, ei ung jente som har vaert utsatt for seksuelle overgrep fra sin far (Irvin 1988).

\section{Omfang av seksuelle overgrep mot barn}

Seksuelle overgrep mot barn har først i de siste 15-20 åra fått oppmerksomhet her i Norge. For bare få år siden trodde vi at seksuelle overgrep mot barn kun skjedde unntaksvis. Når vi blei kjent med at det forekom, unnlot vi ofte å ta det opp fordi vi mente at oppmerksomhet på området ville skape ytterligere problemer. Nå veit vi at slike overgrep er vanlig. Omfanget som oppgis varierer, og er blant anna avhengig av hvilken definisjon på seksuelle overgrep som brukes.

Hvilke skader seksuelle overgrep innebærer for barnet, vil variere. Mindre alvorlige overgrep som skjer én gang, der overgriperen er en fremmed og der barnet blir tatt vare på av foreldrene, vil ofte ikke medføre større problemer for barnet. Når barnet blir utsatt for alvorlige overgrep av en omsorgsperson og barnet ikke får hjelp eller støtte, kan barnet slite med store psykiske skader.

\section{Seksuelle overgrep mot barn og selvmordsatferd, er det en sammenheng?}

På samme måte som seksuelle overgrep har også selvmord i betydelig grad vært forbundet med tabu og fordommer (Retterstøl 1998). Likevel har vi i større grad vært oppmerksomme på selvmordsproblematikken.

I klinisk arbeid med barn, ungdom og voksne som har vært utsatt for alvorlige seksuelle overgrep som barn, erfarer vi at selvmordstanker og -handlinger ofte er et aktuelt tema. Selvmordstanker og selvskadende atferd er vanlig hos jenter som har vært utsatt for seksuelle overgrep (Smith \& Bentowim 1994). I en rekke unders $\varnothing$ kelser har en vist at det er en sammenheng mellom seksuell traumatisering i barneår og seinere suicidal atferd. Ystgaard gir en oversikt over denne forskningen i dette nr. av Suicidologi, s.7 ff.

Hvorledes skal vi forstå dette? At vonde erfaringer og belastninger bidrar til selvmordstanker og -handlinger, virker umiddelbart forståelig for oss. Alvorlige seksuelle overgrep representerer et traume for barnet. Men er det også noe ved selve det seksuelle overgrepstraumet som innebærer at dette i st $\varnothing$ rre grad enn andre traumer og belastninger skulle bidra til selvmordsproblematikk? I så fall, hvilke konsekvenser får det for vårt terapeutiske arbeid?

\section{Hva innebaerer seksuelle overgrep for barnet?}

Seksuelle overgrep mot barn innebærer at barnet blir trukket inn i en seksualisert relasjon til en voksen, der den voksne bruker barnet for å tilfredstille egne behov på bekostning av barnets behov. Overgriper kan bruke fysisk makt eller trusler overfor barnet. I mange situasjoner er imidlertid maktaspektet lite synlig.

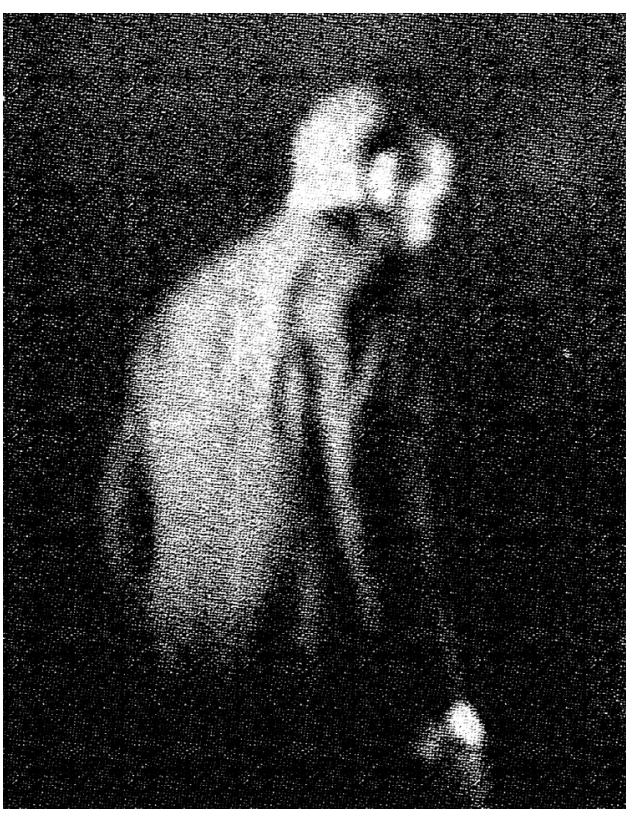

Når barnet blir misbrukt av en person som barnet kjenner eller står i et avhengighetsforhold til, representerer den voksne en autoritet som en forventer at barnet skal respektere eller være glad i. "Klart at du må gi bestefar en klem", "Gjør som tante sier". Barnet kan bli redd for at foreldrene blir sinte dersom det sier noe.
Overgrepene kan foregå over tid, der en ser en utvikling fra mindre til mer alvorlige overgrep, og der barnet blir trukket inn i en overgrepsrelasjon som det i utgangspunktet ikke ser rekkevidden av. Yngre barn forstår heller ikke hva som foregår, og blir forvirra når den voksne kan si at det som foregår er slik det skal være og godt for barnet, selv om barnet opplever situasjonen som følelsesmessig vanskelig eller smertefull. Pålegg om hemmeligholdelse eller barnets angst for de voksnes reaksjoner dersom det sier fra, gjør også at barnet ikke får hjelp til å forstå hva som foregår.

Fordi barn opplever å være helt avhengige av foreldrene, blir situasjonen spesielt vanskelig når foreldre forgriper seg. Barnet kan være redd for å miste foreldrene dersom det tar opp overgrepene, eller redd for andre konsekvenser dersom overgrepene blir kjent. For å unngå dette ser vi derfor at barnet kan undertrykke egne følelser, behov og reaksjoner i forhold til overgrepet og på denne måten tilpasser seg situasjonen. Barnet kan utvikle skamfølelse: "Det er noe galt med meg når far eller den snille mannen i nabolaget kan gjøre dette med meg", eller skyldfølelse: "Det er min skyld, for jeg var med på det, stoppa det ikke." Barnet fikk kanskje også gaver eller ekstra oppmerksomhet, som kan $\varnothing$ ke skyldfølelsen. På denne måten kan barnet oppleve at det selv har ansvar for overgrepet, særlig når maktaspektet er utydelig. Fordi barnets følelser og behov blir tilsidesatt, blir barnets selvfølelse skadet, og barnet utvikler en utrygg identitet.

Skader ved seksuelle overgrep må også forstås på bakgrunn av den sosiale og kulturelle kontekst som overgrepet finner sted innafor, med tabuisering og hemmeligholdelse. Kulturelt sett er seksuelle overgrep forbundet med stigma. Dette bidrar til barnets opplevelse av å være $\varnothing$ delagt. Foreldre og andre personer i barnets omgivelser kan også ha problemer med å tørre eller orke å se hva barnet blir utsatt for. Ofre for overgrep vil derfor 
ofte oppleve at overgrepet er deres dypeste og mest skamfulle hemmelighet (Hildebrand \& Christensen 1986). For utvikling av en positiv selvopplevelse og identitet er barnet avhengig av å bli sett, forstått og bekrefta av sine foreldre. Hemmeligholdelsen av overgrepene betyr for barnet at det ikke blir sett. Det innebærer også at barnet ikke får hjelp av foreldrene til å korrigere sine opplevelser og oppfatninger, noe som bidrar til skadene som vi kan se etter alvorlige seksuelle overgrep.

\section{Selvmordsatferd som konse- kvens av seksuelle overgrep}

For barn og ungdom som blir utsatt for seksuelle overgrep kan, som i sitatet innledningsvis, selvmord framstå som en løsning i en situasjon der alle andre utveier oppleves stengt. Men vi ser alvorlig selvmordsatferd også lenge etter at aktuelle overgrep har opphørt.

Selvmordsatferd og selvskading kan være en måte å regulere den psykiske smerten på som oppstår som følge av overgrepene (Wagner \& Linehan 1997). Seksuelle overgrep vil også få konsekvenser for barnets utvikling, gjennom skader i forhold til barnets følelser, sosiale tilpasning og kognitive fungering. Barnet utvikler dermed en sårbarhet i forhold til påkjenninger som kan være bakgrunnen for selvmordsatferd.

Men også de reaksjoner som vi ofte ser i tilknytning til et seksuelt overgrepstraume, kan innebære at selvmordstanker og -atferd er nærliggende. I overgrepsituasjonen opplever barnet tap av kontroll. På grunn av det sviket som overgrepet innebærer og fordi det heller ikke var noen der som hjalp eller forsto, vil barnet oppleve at det ikke kan ha tillit til omgivelsene. Opplevelsen av håpløshet $\mathrm{og}$ hjelpeløshet i tilknytning til overgrepene er en erfaring som barnet tar med seg. At det ikke finnes noen løsninger, og manglende tillit til muligheter for at andre kan hjelpe er også sentrale tema i ei selvmordskrise.

For å beskrive det barn utsettes for, som over tid lever i en alvorlig overgrepssituasjon, bruker Shengold betegnelsen "sjelemord". Et slikt sjelemord innebærer et ytre traume som er så overveldende at

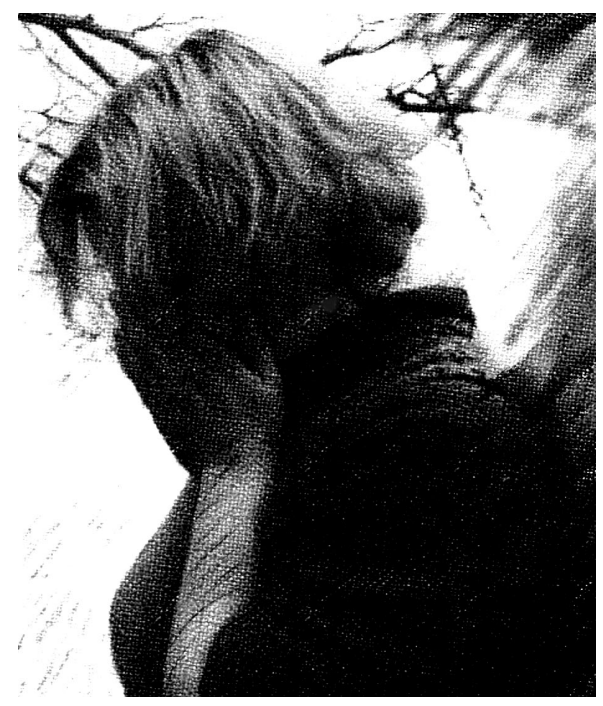

barnets mentale apparat blir oversv $\varnothing \mathrm{mt}$ med følelser. Dette skremmende "for mye" krever massive bevissthetsendrende forsvar slik at barnet fortsatt kan tenke, føle og leve (Shengold 1989). Vi kan si at et sjelemord innebærer helt eller delvis en psykisk tilintetgjørelse. Overgangen til den fysiske tilintetgjørelsen som selvmordet innebærer, blir ikke så stor. Det er en tydelig parallellitet $\mathbf{i}$ tema når vi sammenlikner det seksuelle overgrepstraumet med selvmordskrisen.

\section{Terapeutisk dilemma}

Ved traumer kan vi beskrive to grunnleggende kognitive og emosjonelle reaksjonsmønstre, tilnærming og unngåelse. Tilnærming innebærer at en gradvis forholder seg til det som faktisk har skjedd og de følelsesmessige reaksjonene som hendelsen vekker. Særlig i den akutte situasjonen eller ved vedvarende store påkjenninger vil en strategi som innebærer unngåelse, være en måte å beskytte seg på. En beskytter seg emosjonelt ved å unngå å ta inn over seg de følelsesmessige reaksjonene som traumet innebærer. Kognitivt kan en også beskytte seg ved å utelate fra bevisstheten helt eller deler av det som faktisk skjer. Dette kan der og da fungere som en mestringsstrategi. En del barn vil utvikle dissosiative symptomer som varer ved for å forsvare seg mot den psykiske smerten ved overgrep (Hornstein \& Putnam 1996). På sikt vil en slik unngåelse eller dissosiering ha omkostninger. Bearbeiding av traumet innebærer derfor en tilnærming til det som har hendt.

Når vi som behandlere mener at tidligere seksuelle overgrep har betydning for aktuell selvmordsproblematikk og der en bearbeiding av tidligere overgrep er vesentlig for bedring, står vi overfor et terapeutisk dilemma. I behandlingen vil en ofte nærme seg de traumatiske hendelsene gradvis, for sammen med klienten å utforske hvilke konsekvenser overgrepene har fătt og de følelsesmessige reaksjonene som overgrepene innebærer. Dette vil ha som siktemål at klienten skal integrere hendelsen og dens betydning i sitt liv. I en slik prosess vil smertefulle følelser og minner bli aktivert. Dette kan igjen føre til sterke selvmordsimpulser eller problemer med å kontrollere selvskadende atferd. For å redusere suicidalitet vil vi arbeide med overgrepstraumet. Når vi i dette arbeidet nærmer oss smerten ved overgrepet og reaksjonene som overgrepet innebar, kan vi nettopp $\varnothing$ ke suicidalfaren. I behandlingsopplegg må vi derfor vurdere aktuell suicidalfare. Når dette er et problem, blir det viktig at vi ikke aktiverer mer smerte og flere minner om vanskelige hendelser enn klienten kan forholde seg til. Vi kan også sammen med klienten vurdere om det er mulig i ei avgrensa periode å motstå impulser til selvmordsatferd, slik at en kan arbeide terapeutisk med vanskelige følelser og minner ved å etablere det vi kan kalle et "terapeutisk rom". Innleggelse kan være aktuelt for å gi tilstrekkelig st $\varnothing t t e$ i perioder av behandlingen. Arbeid med mestringsressurser blir vesentlig, både for å motstå selvmordsimpulser, og fordi opplevelse av mestring ofte er blitt et problem ved overgrepstraumer.

Når barn blir utsatt for overgrep fra tillitspersoner, er tillitsbruddet og opplevelsen av å være sviktet spesielt viktig. I behandlingstilbudet vil arbeid med disse temaene stå sentralt. St $\varnothing$ tte fra foreldrene er avgjørende for å redusere skader etter overgrep. Foreldrene b $\varnothing \mathbf{r}$ derfor i den grad det er mulig trekkes inn i behandlingsopplegget.

\section{Klinisk eksempel}

Eva, 16 år, blei innlagt på sjukehuset etter å ha tatt en overdose med medikamenter. Eva bor sammen med mor, bror på 14 år og de siste 10 årene også med mors samboer Ole. Foreldrene til Eva skilte seg da hun var 3 år gammel. Hun har regelmessig kontakt med far som bor i samme by. Eva går nå i 10 klasse på ungdomskolen. Hun har søkt helse- og sosiallinja på videregående skole, men er 
usikker på om hun kommer inn. Rådgiver mener at hun har god mulighet til å komme inn dersom hun forbedrer karakterene sine litt nå i vår. Eva oppfattes å ha gode evner, men hun har alltid vært noe ukonsentert og viser variabel innsats i skolearbeidet. Eva kan være noe varierende i hum $\varnothing$ ret. Hun har noen venninner, men ingen som hun har hatt et nært forhold til. De siste ukene har hun vært sammen med Petter, det er nettopp blitt slutt. Hun har hatt mindre konflikter med mor og Ole, men ikke mer enn det en oppfatter er vanlig mellom foreldre og tenåringsbarn.

Mor hadde funnet Eva på rommet hennes etter at hun hadde tatt tablettene. Noen timer før hadde Eva og mor kranglet. Eva ville reise på hyttetur med venninner. Mor hadde sagt nei, fordi hun mente at det kom til å bli drukket alkohol på hytteturen. Mor skulle selv reise bort denne helga, ungene skulle være heime med Ole. Før Eva for på rommet sitt, hadde hun skreket til mor: "Du skjønner ingen ting".

Mor og Ole blir med på sjukehuset. I samtale med sosionomen der sier mor at hun tror bakgrunnen for selvmordsfors $\varnothing$ ket er at Eva ikke fikk reise på hytteturen. Dette kommer i tillegg til kjærestebrudd, Evas usikkerhet med hensyn til om hun kommer inn på førstevalget sitt på videregående skole og omgivelsenes forventninger om at hun skal konsentere seg mer om skolearbeidet.

I tillegg til felles samtale vil sosionomen også snakke med Eva aleine. Hun oppfatter en tristhet hos Eva, bak en noe røff fasade, og et svært dårlig selvbilde. I samtalen bekrefter Eva mors opplysninger. Hun kommer også med en bemerkning om at hun ikke ville være heime med Ole. Sosionomen har erfart at noen unge jenter som har vært innlagt etter intox, har vært utsatt for seksuelle overgrep, og spør Eva om dette. Eva forteller etter noe nøling at hun over tid hadde vært misbrukt av Ole, mors samboer. Dette starta da Eva var lita. Da de var mindre hjalp Ole mor med å legge barna. Eva opplevde at Ole gjorde ting som hun syntes var ekle når han ville vaske henne. Etter hvert blei overgrepene mer alvorlige, selv om det ikke skjedde så ofte. Eva skjønte først ikke hva som foregikk. Ole hadde sagt at han og Eva hadde dette som en hemmelighet sammen. Eva hadde antydet overfor mor at forholdet til Ole var vanskelig. Men mor oppfattet det som vanlige foreldre/barn-konflikter. Eva var også redd for at mor ikke ville tro på henne dersom hun sa noe, og hun ville ikke фdelegge forholdet mellom Ole og mor, eller være årsak til at Ole kom i fengsel. Mor hadde sagt at hun var glad i Ole og at han tok seg så godt av barna. Ole var også grei på mange måter. Eva opplevde at hun hadde skyld i det som skjedde siden hun ikke hadde stoppet Ole eller hadde sagt fra tidligere.

Da Eva begynte å være sammen med Petter fikk hun store vansker med fysisk kontakt, Petter spurte hva det var med henne. Dette forsterket opplevelsen hennes av å være $\varnothing$ delagt. Hun hadde strevet med selvmordstanker i noen måneder, og flere ganger kuttet seg selv.

De siste to årene hadde Ole ikke gjort nye overgrep. Men Eva var stadig redd for at han ville fors $\varnothing$ ke seg igjen. Derfor var hun også redd for å bli aleine med han i helga. Hun hadde et bra forhold til sin far, men visste at han ville være opptatt i helga: Dessuten var han etablert med ny familie, og hun ville jo fortsatt være den samme selv om hun flyttet til han. Nå opplevde hun at alt var blitt umulig og hun selv var mislykka. Hun ville bare komme vekk fra alt sammen og hadde derfor tatt tablettene.

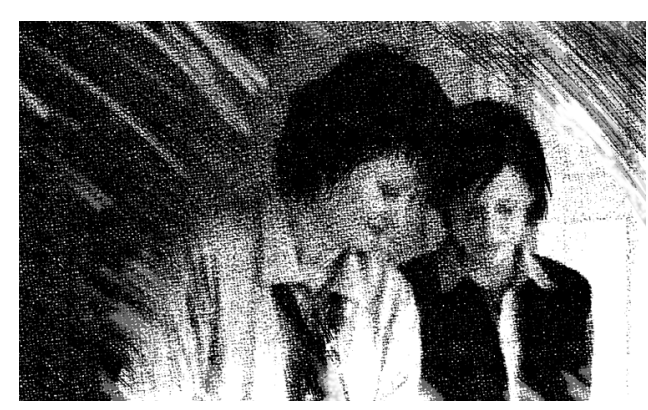

Sammen med Eva fortalte sosionomen til mor hva Eva hadde sagt. Sosionomen tok også kontakt med barnevernet. I denne saken trodde mor på det Eva fortalte og st $\varnothing$ tta henne. Denne støtten var svært viktig for at Eva skulle gjenvinne tillit til mor og til omverden generelt. Ole flytta fra familien. Han benekta overgrep. Eva opplevde likevel at han indirekte aksepterte ansvar for det som hadde foregått. Eva fikk behandlingstilbud i barne- og ungdomspsykiatrien. I samtaler der fikk hun hjelp til å forstå hva som hadde skjedd da hun var blitt misbrukt, at hun ikke hadde skyld eller var $\varnothing$ delagt. Gradvis kunne hun åpne opp for følelser som smerte, sinne, angst, ambivalens og andre reaksjoner i forbindelse med overgrepene, og bearbeide disse. Gradvis gjenvant hun også opplevelse av mestring i eget liv og tillit til egen kompetanse. Hun sluttet å kutte seg, og fikk tro på at livet er verd å leve. Mor fikk også tilbud om samtaler, der et viktig tema var hennes opplevelse av å ha sviktet datteren, siden hun ikke hadde sett hva som foregikk. Gjennom dette viste hun en større åpenhet overfor Eva, slik at hun igjen kunne fă tillit til mor og ta i mot hennes omsorg. I felles samtaler tok en opp forholdet mellom mor og datter. Broren og faren til Eva blei også trukket inn i disse samtalene.

\section{Konklusjon}

Vi finner en sammenheng mellom alvorlig seksuell traumatisering av barn og selvmordsatferd. I behandling av selvmordsnære personer bør vi derfor være oppmerksomme på muligheten av seksuell traumatisering. Og i arbeid med personer som har vært utsatt for seksuelle overgrep må vi avklare mulig suicidalproblematikk.

Sentrale tema i behandling både når det gjelder overgrepstraumer og ved selvmordskriser vil være hvorledes klienten kan gjenvinne opplevelse av kontroll og mestring i eget liv, utvikle selvfølelse, tillit til omgivelsene og tro på at livet har muligheter.

\section{Litteratur:}

Hildebrand E, Christensen E. Familier med sexuelt misbrug af børn. Danmark: Hans Reitzels Forlag, 1986

Hornstein NL, Putnam FW. Abuse and the development of dissociative symptoms and dissociative identity disorder. I: Pfeffer CR, red. Severe stress and mental disturbance in children. Washington DC: American Psychiatric Press, 1996

Irvin H. Abby, min elskede.

Oslo: Den norske Bokklubben, 1988.

Retterst $\varnothing 1$ N. Selvmord i kulturhistorisk perspektiv. Nytt i suicidologi 1998; 3(3):3-5

Shengold L. Soul Murder: The effects of childhood abuse and deprivation. New Haven CT: Yale University Press, 1989.

Smith M, Bentovim A. Sexual abuse. I: Rutter M, Taylor E, Hersov L, red. Child and adolescent psychiatry. London:Blackwell science, 1994

Wagner AW, Linehan MM. Biosocial perspective. I: Zanarini MC. Role of sexual abuse in the etiology of borderline personality disorder. Washington DC: American Psychiatric Press,1997

Ystgaard M. Familien og selvmordsatferd - noen hovedtrekk fra forskningen.

Suicidologi 1999; 4 (2): 7-9

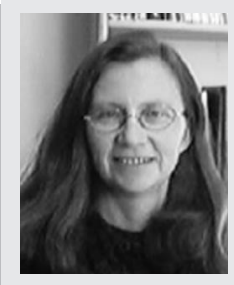

Ingebjørg Hestetun er ansatt v/SSFF og er spesialist $\mathrm{i}$ klinisk psykologi. Hun har i mange år arbeidet innenfor barne-og ungdomspsykiatrien. Nå jobber hun bl.a. med Aker-prosjektet. 